\title{
Genealogical Representations of Monastic Communities in Late Medieval Art
}

\author{
Christian Nikolaus Opitz \\ Depicting Spiritual Genealogies
}

Genealogical representations of monastic communities are a common subject in the arts of late medieval Europe. So common in fact that we tend to take their emergence as almost self-evident when in reality it is anything but. After all, genealogies in the stricter sense of the term refer to groups bound together by biological descent and, considering the vows of chastity required from all members of Christian religious orders, this type of social cohesion was, strictly speaking, unavailable to communities of friars, monks, and nuns. However, as is also discussed in Christina Lutter's contribution to this volume, the concept of familia was frequently adopted by monastic communities as a means of selfconception and self-representation, including all the biological and, more importantly, sociological implications it entails.

Just like family, the concept of genealogy is about more than just real or imagined blood ties and kinship relations_-as Gabrielle Spiegel put it, genealogies are "symbolic forms" and "expressions of social memory". ${ }^{1}$ One could perhaps say that the potential of genealogy as a symbolic form lay (and still lies) precisely in its association with kinship relations, and that these associations are what made it an attractive choice for the self-representation of groups that lacked such ties. It comes as no surprise, then, that genealogical representations, both in written and in pictorial form, were frequently employed by monastic communities. And although in the following I will mainly be concerned with late medieval Europe, it is important to note that the same or similar phenomena are also to be found in other geographical and cultural contexts: depictions of such spiritual genealogies were widespread not only in the visual arts of Europe, but also of Tibet. ${ }^{2}$

In Tibet there is a strong tradition of what modern-day scholars have termed "lineage painting" in monastic contexts from the $13^{\text {th }}$ century onwards. ${ }^{3}$

\footnotetext{
1 Spiegel, "Genealogy", 104, 105 (emphasis added).

2 See Birgit Kellner's contribution in this volume.

3 Kossak, "Lineage Painting", 49-57.

(C) CHRISTIAN NIKOLAUS OPITZ, 2016 | DOI 10.1163/9789004315693_010
}

This is an open access chapter distributed under the terms of the Creative Commons Attribution-

Noncommercial-NoDerivatives 3.o Unported (CC-BY-NC-ND 3.o) License. $h r i s t i a n ~ N i k o l a u s ~ O p i t z ~-~ 9789004315693$ 
Usually, these lineage paintings are thangkas, that is paintings on cloth, showing the spiritual leader of a sect or a monastery surrounded by smaller depictions of his teachers and predecessors (ill. 1). In terms of content, like most genealogies, these images include a certain amount of fabrication, depending on their original context and intention, but a common goal seems to have been to trace back one's lineage to India, the homeland of Buddhism. In formal terms, they follow a tradition of Tibetan religious painting where Buddhas,

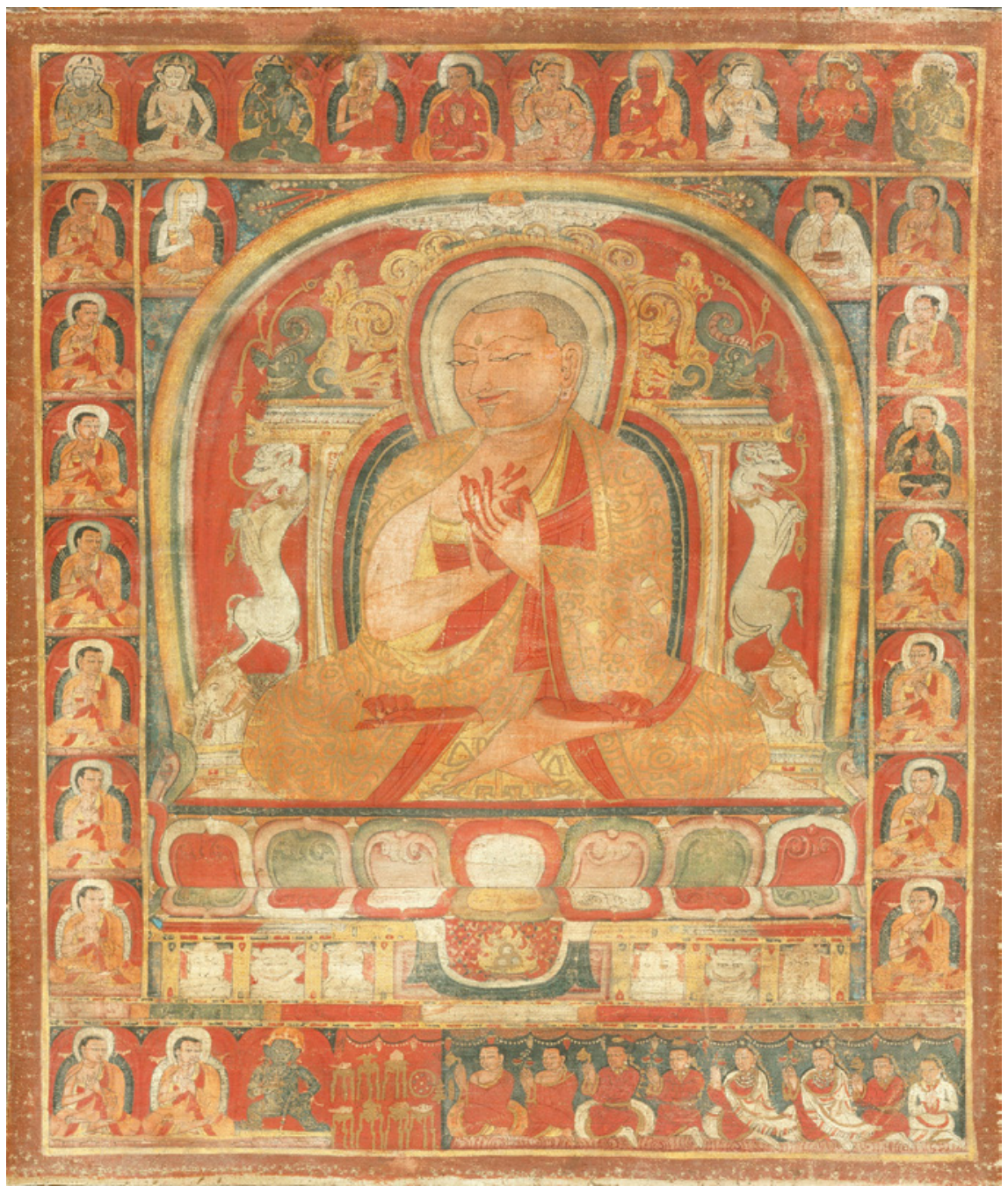

ILLUSTRATION 1

An Abbot and His Lineage, Western Tibet, 14th century or earlier, painting on cloth, Los Angeles County Museum of Art (image: public domain, via www. lacma.org) 
Bodhisattvas and deities were commonly placed in the centre of thangkas, surrounded by smaller depictions of attendants, other Buddhas and lesser deities. ${ }^{4}$ It may be said, therefore, that this kind of spiritual lineage painting appropriates a type of pictorial composition which at the time was already established in religious art of the region.

We encounter similar processes of appropriation when we shift our attention to late medieval Europe: here, the visual model of the genealogical tree was adopted by monastic communities, resulting in the creation of Ordensstammbäume (genealogical trees of monastic orders) (ill. 2). 5 This type of representation enjoyed great success especially in the $15^{\text {th }}$ century, when it was represented in a wide range of artistic media (such as woodcuts, panel painting, mural painting, tapestry) and seemingly employed by all monastic orders of Western Christianity. It was, however, particularly popular with the two largest mendicant orders, the Dominicans and the Franciscans, and, as will be explained below, it seems that it was among these two orders that such images were first developed.

\section{Symbolic Representations of the Dominican Order}

The concept of the genealogical tree, in the guise of the family tree, is of course highly familiar to us today. However, as the Tibetan tradition of lineage painting briefly outlined in my introduction reminds us, a spiritual genealogy could also be depicted in an entirely different way. It is, I believe, important to remember that the use of a tree pattern is not as obvious as it may seem to us. And yet, when we look at modern art historical writing, we find that most of the authors seem to consider the existence of Ordensstammbäume in late medieval art as something that is almost self-evident and does not require further explanation.

A particularly striking case of this attitude is found in Charlotte GutscherSchmid's otherwise excellent discussion of the Dominican Tree in Bern, Switzerland (ill. 2), ${ }^{6}$ perhaps the finest surviving example among of the late medieval Ordensstammbäume. Painted in 1495, this mural painting is located on the screen which separates the nave from the chancel in the former

\footnotetext{
4 Singer, "Painting".

5 Walz, "Von Dominikanerstammbäumen"; Donadieu-Rigaut, Penser en images; Preisinger, Lignum Vitae, 209-33; Ilg, "Quasi lignum vitae".

6 Gutscher-Schmid, Nelken, 97-100, 215-18.
} 


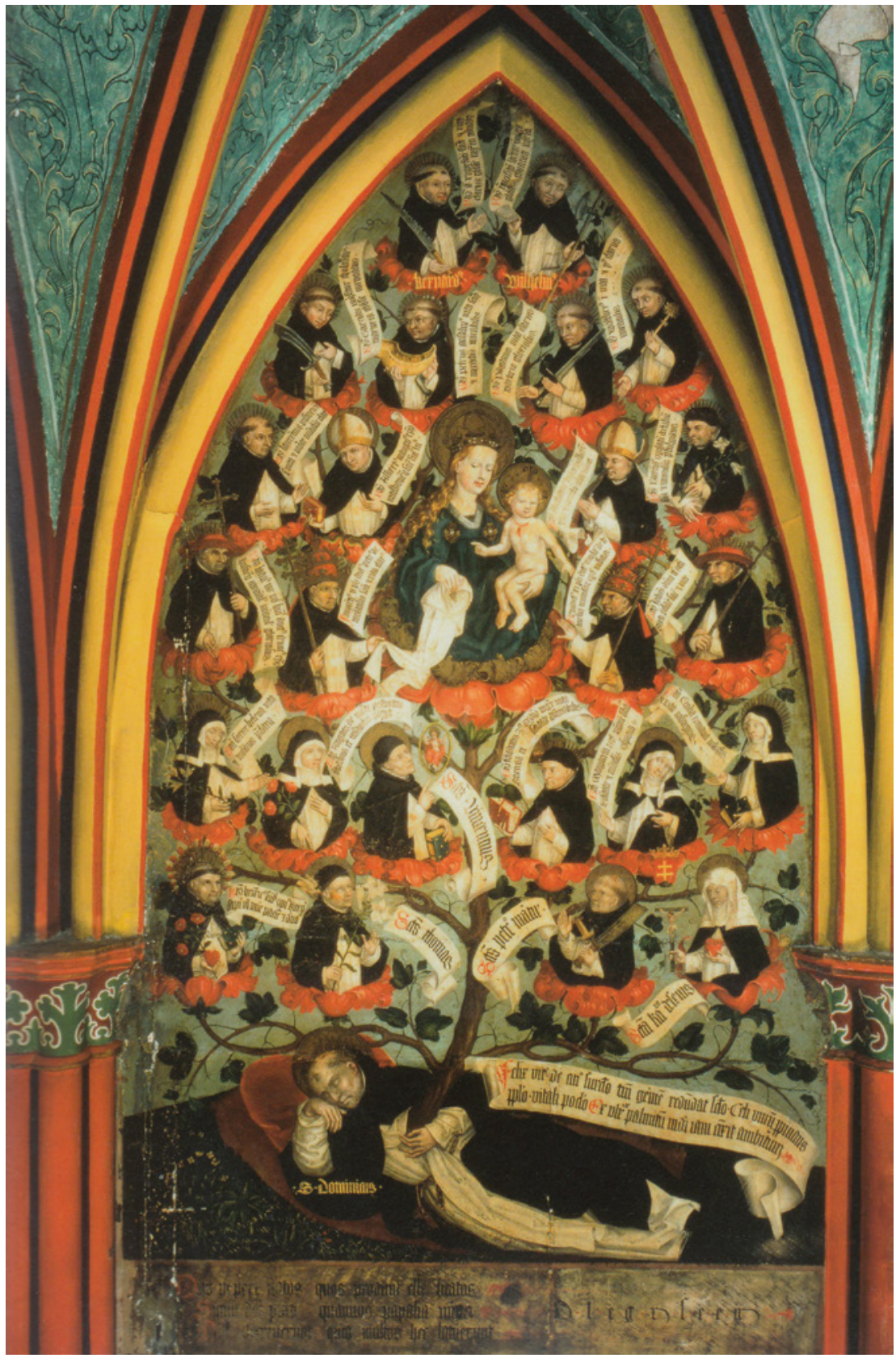

illustration 2 Bernese Carnation Master: Genealogical Tree of the Dominican Order, 1495, wall painting, French Church, Bern (image from: Charlotte Gutscher-Schmid, Nelken statt Namen: Die spätmittelalterlichen Malerwerkstätten der Berner Nelkenmeister, Bern, 2007, p. 87) 
Dominican church in Bern (now commonly known as the French Church). ${ }^{7}$ The image shows St Dominic, the founder of the Dominican order, lying asleep on the floor; from his body there emanates a tree, the branches of which carry the figures of both male and female saints who during their lifetime had belonged to the Dominican order. They are placed in bright red blossoms and arranged around the centrally placed figure of the Virgin Mary with the Infant Jesus.

As Gutscher-Schmid rightly points out, this ideal collective representation of the Dominican Order is derived directly from woodcut models of the same subject, the then new medium of print having played a crucial part in the rapid dissemination of this iconographic type. Then, however, she outright simply states that all genealogical trees of the Dominican Order are ultimately derived from the Chapter House in the Dominican convent of Treviso, Italy. ${ }^{8}$ The main feature of the Treviso Chapter House's pictorial decoration, executed in $135^{2}$ by Tommaso da Modena, ${ }^{9}$ is a sequence of portraits of 40 Dominican saints and scholars, all shown at work at their desks, taking up the upper part of all four walls, interrupted only by an image of the Crucifixion. In the dado zone of the walls, there are three tiers of medallions containing inscriptions: in the upper tier, they list the names of the order's province, in the middle tier the convents in the province Lombardia Inferior (to which Treviso belonged), and in the lower tier the names of the order's generals in chronological order. There can be no doubt that the decorative scheme we find in Treviso is one of the most compelling and comprehensive attempts to visualize the Dominican Order as a whole in all of medieval art, ${ }^{10}$ and with its sequence of portraits and its lists of names it even features elements that may be described as genealogical. ${ }^{11}$ What one looks for in vain, however, is a genealogical tree.

7 Regarding the screen see Schmelzer, Lettner, 86-9o.

8 "Vorbildlich für alle Dominikanerbäume war der Kapitelsaal des Dominikanerklosters von Treviso", Gutscher-Schmid, Nelken, 100.

9 See Gibbs, Tommaso, 50-87, 258; Stein-Kecks, Kapitelsaal; 346-55; El Saman, "Studien”, 133-47; Donadieu-Rigaut, "L' image".

10 See also the Cappella Spagnola in Florence, for which see below.

11 As mentioned, the order's generals are listed chronologically, and the convents of Lombardia Inferior are also arranged by their foundation date. As regards the portraits of Dominican saints and scholars, the situation is slightly more ambiguous: while they are not arranged in a strict chronological sequence, temporal aspects seem to have been considered nonetheless (for instance, there is a clear separation between those who lived in the 13th and those who lived in the 14th century); see El Saman, Studien, $136-43$. 
All in all, the decoration of the Treviso Chapter House presents us with a way of depicting an order and its genealogy that is markedly different from what we have seen in Bern. It is not easy to believe, therefore, that the murals in Treviso could have been the model for the later Ordensstammbäume. Such a proposition only makes sense if one takes the concept of the genealogical tree so much for granted that the progression from a linear sequence of portraits to such a tree seems like a small, logical next step. In fact, however, it is quite remarkable and far from self-evident that the 15 th century Dominicans employed genealogical trees as a medium of self-representation at all.

\section{The Emergence of the Family Tree}

Contrary to popular belief, family trees as we know them, were not common at all during the Middle Ages-like witch-hunts, they are essentially an early modern phenomenon which only gained wider significance around and after $1500 .{ }^{12}$ If for instance a lord or a king wanted to adorn the hall of his castle with a depiction of his genealogy, from the $13^{\text {th }}$ to the late $15^{\text {th }}$ century the standard format was to present his predecessors in a plain, uninterrupted line of standing or, occasionally, seated figures. ${ }^{13}$ In this respect, then, the sequence of Dominican portraits in Treviso corresponds perfectly to what was then the usual way of visualizing a genealogy in a monumental format.

If we look at other artistic media, such as manuscript illumination, the situation is slightly different and more complex. In manuscripts, we find various kinds of schematic representations of genealogies, some of which already look relatively close to what we are used to calling a family tree. ${ }^{14} \mathrm{~A}$ good example of this kind of imagery are the Kuenring genealogies in the liber fundatorum of Zwettl Abbey in Lower Austria, the so-called Zwettler Bärenhaut, dating to c. $1310 .{ }^{15}$ Here, rather than just a line of figures, we already have a sort of diagram, the various members of the family being included in medallions

12 See Klapisch-Zuber, "Genesis".

13 Prominent examples were once found in: Paris, Palais de la Cité, c. 1300, see Bennert, "Art"; Karlstein Castle, c. 136o, see Stejskal, "Rekonstruktion"; Munich, Alter Hof, c. 146o, see Hoffmann, Meister, 197-200, 240-46; Esztergom Castle, c. 1470, see Radocsay, Wandgemälde, 139-41.

14 See for instance Worm, "Arbor"; Norbye, "Arbor".

15 , Stiftungen-Buch, ed. Von Frast; Liber fundatorum, ed. Rössl. On the liber fundatorum see also Maria Mair's forthcoming PhD, written in the VISCOM project, and Christina Lutter's contribution in this volume as well as Lutter, "Zisterzienser", 148-60. 
spread across the entire length of the page, arranged chronologically in several registers and connected by double lines.

In some instances, contemporary writers even referred to diagrams such as those in the Bärenhaut as "trees", and there are some examples for such diagrams where the lines connecting the single individual family members are decorated with leaves so that they look like actual branches. ${ }^{16}$ But while writers invoked the concept of the genealogical tree from the high Middle Ages onwards, and while painters would occasionally hint at the plant metaphor in depictions of families and lineage, these medieval images still differ from modern family trees in one key aspect: the tree metaphor relies essentially relies on the idea of upwards growth, while the diagrams we encounter in the Bärenhaut and elsewhere show lineages arranged from top to bottom. This top-down structure allowed medieval illuminators to place the Spitzenahn (the founder of a family or dynasty) in the most prestigious position on top of the page and to show his progeny as literally descending from him. And, of course, it also corresponds to the usual way of reading a page in a manuscript from top to bottom. As Christiane Klapisch-Zuber has shown, it is likely that medieval artists avoided the tree structure for lineage paintings because it would have meant reversing the usual reading order and placing the Spitzenahn in the lowest position, at the roots of the tree. ${ }^{17}$

There is one prominent exception to this rule, and that is the so-called Tree ofJesse (ill. 3), an allegorical image of the genealogy of Christ which had already developed in the course of the high Middle Ages. ${ }^{18}$ The pictorial subject of the Tree of Jesse is based on a combination of Christ's ancestors as listed in the gospel of St Matthew with certain passages from the Old Testament prophecies of Isaiah, especially Isaiah 11,1: "And there shall come forth a rod out of the stem of Jesse, and a Branch shall grow out of his roots". The resulting images show Jesse, the father of King David, lying asleep as a rod or tree grows out of his body, the fruits and branches of the tree being the ancestors of Christ up to the Virgin Mary, who is shown holding the Infant Christ himself. Since the composition culminates in Christ, in the case of the Tree of Jesse it was perfectly reasonable, if not downright necessary to retain the upward thrust inherent in the tree metaphor suggested by Isaiah's prophecies. That way Christ is placed in the highest-ranking position and the image as a whole can be read as an ascent towards spiritual perfection. ${ }^{19}$

\footnotetext{
16 Klapisch-Zuber, “Genesis”, 113-15.

17 Klapisch-Zuber, “Genesis", 115-18.

18 See Bogen, “Träumt Jesse?”; Gelin, "Stirps”.

19 Klapisch-Zuber, “Genesis", 120-22.
} 


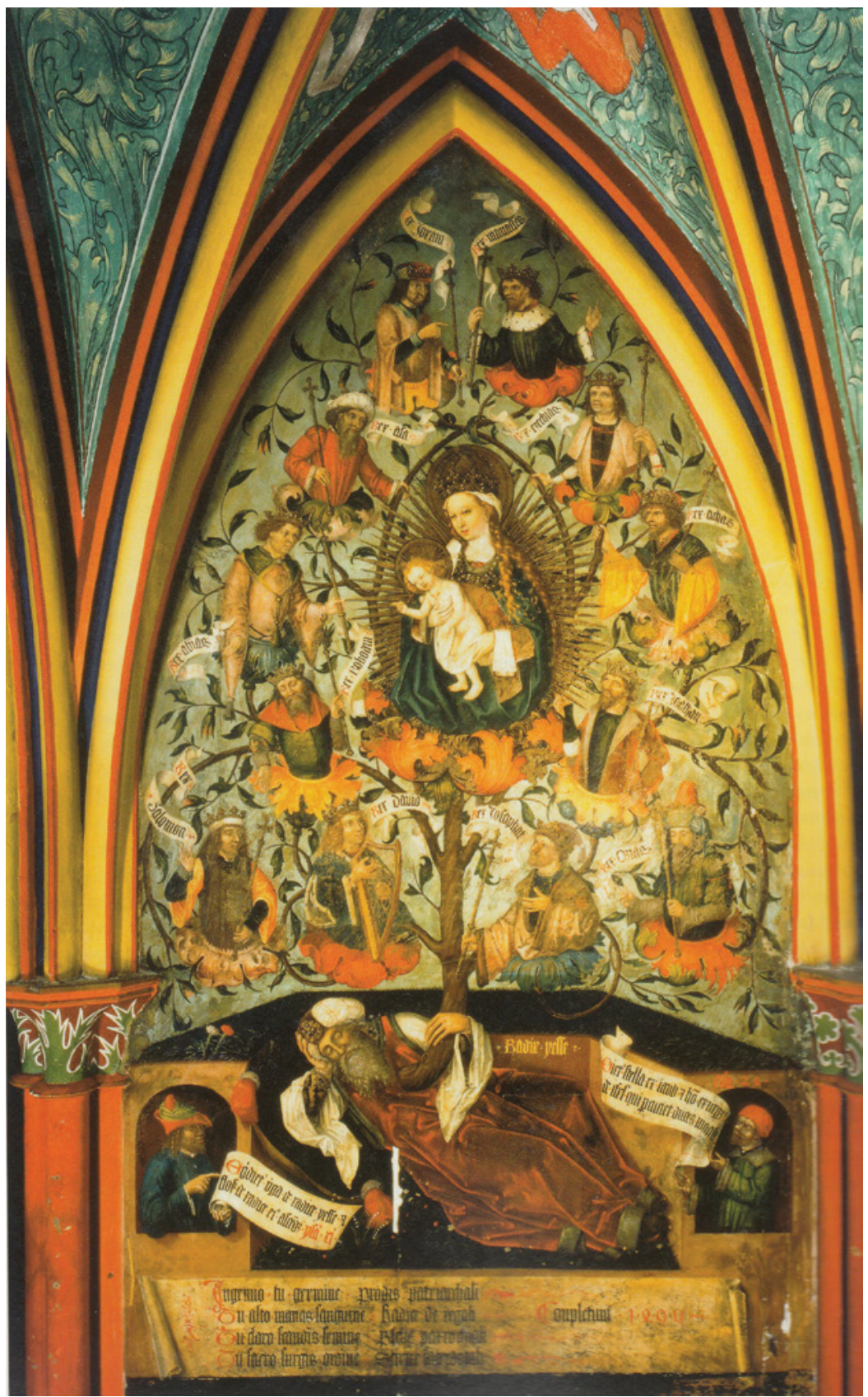

ILlustration 3 Bernese Carnation Master: Tree of Jesse, 1495, wall painting, French Church, Bern (image from: Charlotte Gutscher-Schmid, Nelken statt Namen: Die spätmittelalterlichen Malerwerkstätten der Berner Nelkenmeister, Bern, 2007, p. 86) 


\section{Genealogical Trees in the Dominican Order}

Now, if we return to the Dominican Ordensstammbäume of the 15th century, it is instantly evident that they are modelled directly upon the Tree of Jesse, and nowhere is this more evident than in Bern, where the Dominican genealogy is actually placed face to face with a contemporary image of that very subject (ill. 2-3). Indeed, Dominican genealogies not only show the tree as emanating from the reclining figure of St Dominic in the same way as the genealogy of Christ emerges from the sleeping Jesse, most of them even include the Virgin Mary with the Infant Jesus in a similarly prominent position. In Bern, her inclusion among the Dominicans is justified by the fact that she is shown handing the order's white habit to one of them, an episode recalling the legend that the habit used by the Dominicans had first been presented in a vision to one of the friars by the Virgin herself. ${ }^{20}$ In this way, another element which was crucial to the order's identity and visual appearance could be introduced into these painted self-representations. And, based on Klapisch-Zubers considerations regarding upwards versus downwards structures in genealogical representations, one could perhaps ask whether the inclusion of Jesus and Mary also helped to justify the upwards movement of the composition and the placing of St Dominic in the more humble bottom position.

It has to be noted, though, that the Virgin Mary is a relatively late addition to Dominican genealogical trees. She is still absent in the earlier versions of the subject, most notably in the famous woodcut illustration(s) from Johannes de Turrecremata's book of Meditationes. Turrecremata, a Roman cardinal and Dominican, had first published his book of meditations in Rome in 1467. It was, famously, the first book printed in Italy to include woodcut illustrations. ${ }^{21}$ While most of the illustrations - based on a series of now lost frescoes in the cloister of the Dominican convent of Santa Maria sopra Minerva in Rome ${ }^{22}$ contain scenes from the Bible, one of them shows a genealogical tree of the Dominican Order (ill. 4) remarkably similar in its general layout to what we have seen in Bern. Turrecremata's book proved to be highly popular, and several more editions with only small variations in the illustrations were published before 1500 . Thus it became one of the main vehicles for spreading the iconography of the Dominican Ordensstammbaum across Europe. As indicated, however, the genealogical tree in the Meditationes does not include an

\footnotetext{
20 Gutscher-Schmid, Nelken, 217.

21 De Gregori, Chiostro.

22 See Bourgeois, Reconstructing the lost frescoes.
} 


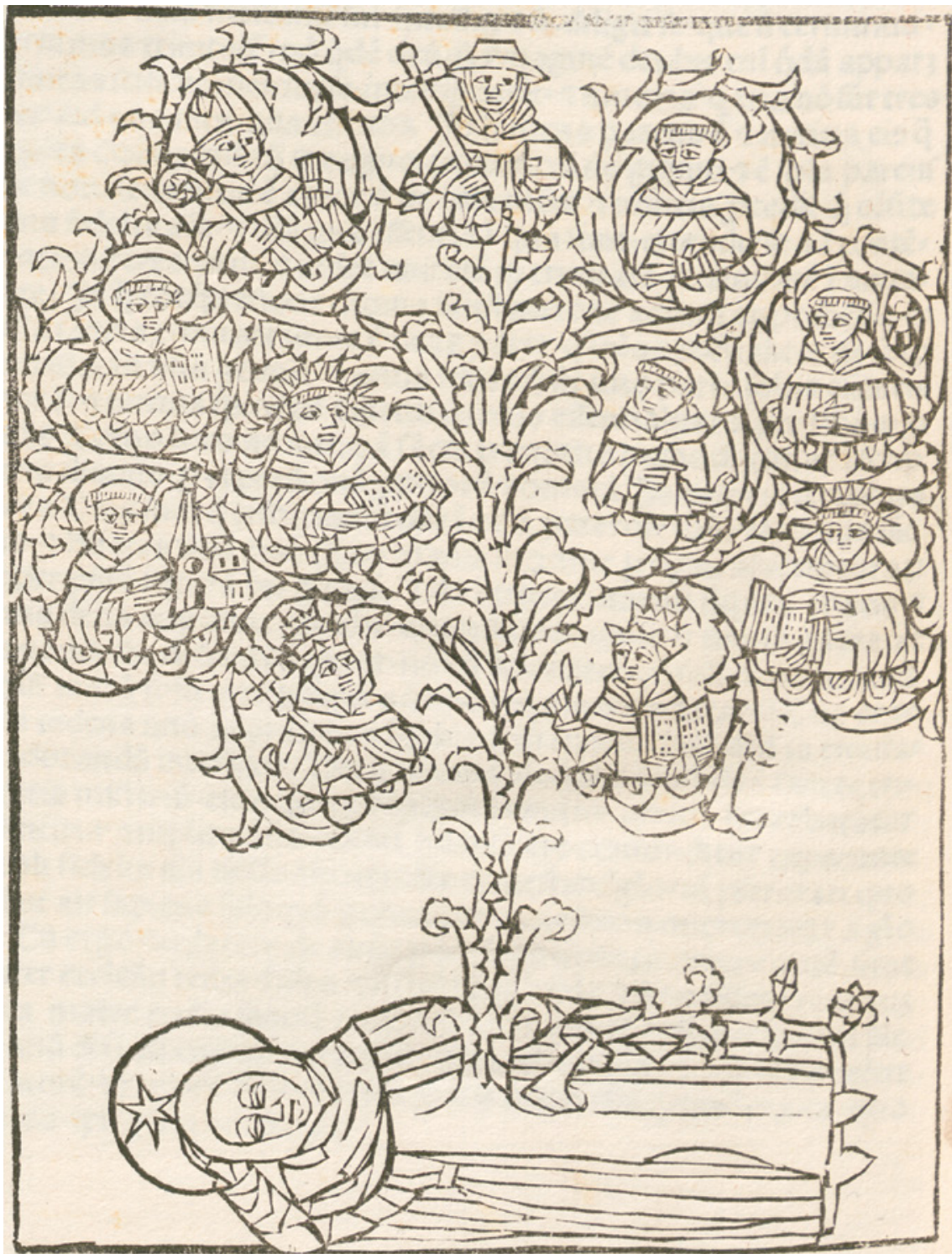

\section{Banctus Dominteus.}

ILlustration 4 Genealogical Tree of the Dominican Order, from:Johannes de Turrecremata, Meditationes, Rome, 1473 (image: public domain, via Bayerische Staatsbibliothek, Munich). 
image of the Virgin Mary, but the sleeping St Dominic as the source of the tree is featured prominently at the bottom of the image.

The fact that Dominic, like Jesse, is shown as sleeping adds another important aspect to the composition that may help to explain why the scheme of the Tree of Jesse was appropriated in self-representations of monastic orders in the first place: it suggests that the genealogical tree itself is a dream vision experienced by the order's founder himself. ${ }^{23}$ While the image as a whole presents the viewer with a visualization of the order's past, it can also be read as a vision of its future as experienced by St Dominic. One might therefore argue, therefore, that the concept of upward growth inherent in the tree metaphor was deemed suitable because these images are not (only) representations of past descent but also and perhaps even more of future expansion. What the image conveys is, in a way, the teleological aspect inherent in genealogy, i.e. a sense that the present may be viewed as a fulfilment of the past while also bearing the promise for continuation into the future. ${ }^{24}$

The idea of a dream vision representing an entire order in the shape of a tree appears quite early on in the history of the mendicant orders, especially with the Franciscans (also known as the Friars Minor). As early as the 13th century Fioretti di San Francesco, one reads of a friar who "saw in a vision a beautiful, large and very strong tree, the root of which was of gold, and its fruits were all men and all of them were Friars Minor. Its main branches were distinguished according to the number of the order's provinces, and each branch had as many friars as there were in the entire province of that branch". ${ }^{25}$

It is important to note that this passage does not allude to concepts like lineage or family at all - while it makes use of the tree metaphor, what we have here is not a genealogical tree. Indeed, all kinds of tree metaphors and tree diagrams, such as Trees of Virtues and Vices, were extremely popular throughout the Middle Ages, and most of them had very little if anything to do with genealogy. ${ }^{26}$ The Franciscans in particular were fond of tree metaphors, both in their writings - most prominently St Bonaventure's Lignum Vitaeand in their images. ${ }^{27}$ At least the early 14th century onwards one frequently

\footnotetext{
23 On the aspect of the dream vision see Bogen, “Träumt Jesse?" 223-31.

24 See Birgit Kellner's contribution in this volume.

25 “...vide in visione uno arbore bello e grande e molto forte la qual radice era d'oro, ifrutti suoi erano uomini e tutti erano frati Minori. I rami suoi principali erano distinti secondo el numero delle Province dell'Ordine, e ciascun ramo avea tanti frati, quanti n'era nella Provincia piena per quel ramo". I Fioretti, ed. Sarri, p. 198.

26 See Berns, "Baumsprache"; Bolzoni, Rete.

27 Preisinger, Lignum vitae.
} 
finds elaborate depictions of diagrammatic trees in Franciscan contexts, most importantly images of the Tree of Life, developed from the writings of Bonaventure and others. In these images Christ's cross is transformed into a tree, the branches of which are inscribed with short texts, often excerpts from the writings of Bonaventure, meditating on the life and death of Christ. More such inscriptions are inserted in medallions, representing the fruits of the tree, which are placed among the branches. In some examples, these medallions contain not merely words but small depictions of scenes from the Life of Christ. The ends of the branches grow into images of prophets and evangelists.

By the second half of the 14th century the Franciscans had developed this type of image further, turning it into Franciscan Trees. While these still retained the central image of the crucified Christ, they now placed the figure of St Francis right underneath it, symbolizing the trunk of the tree; the scenes in the medallions were now scenes from the life of St Francis rather than from the life of Christ, and, most importantly in this context, the prophets and evangelists at the ends of the branches were substituted by saints from the Franciscan order. It is not quite clear how widespread these early Franciscan trees ever were. Today only two fragmentary examples survive, both of them large-scale murals, one in Verona, one in Padua. ${ }^{28}$ It seems, however, that the iconographic model was at least prominent enough to be adopted by the Dominicans as well: at the end of the 14th century, a Dominican Tree of this type was painted on the walls of the cloister, the so-called Chiostro Verde, in Santa Maria Novella in Florence. ${ }^{29}$

This fresco was not an isolated image but has to be seen in connection with a slightly earlier scheme of decoration in the same cloister. The vaults of the Chiostro Verde were painted with no fewer than 96 roundels, each containing the portrait of a haloed Dominican carefully identified by an inscription. ${ }^{30}$ While these inscriptions are now mostly illegible, there can be little doubt that these painted figures were intended to present the order as a whole and through the depiction of so many saintly members stress the order's central place in the wider Christian community. Placed in the immediate vicinity of the entrance from the cloister to the church, the fresco of the Dominican Tree seems like a condensed and slightly more complex variation of the vault

\footnotetext{
28 See Simbeni, "Lignum Vitae"; Preisinger, "Bilder”; Preisinger, Lignum Vitae, 209-23.

29 El Saman, Studien, 225-27; Ilg, "Quasi lignum vitae", 203-04.

30 Cannon, Religious Poverty, 182-85.
} 
decoration, almost a kind of succinct summary to be viewed just before entering the church.

In many respects, the decoration of the Chiostro Verde at Santa Maria Novella seems to resume the strategy of symbolic representation employed by the much more famous frescoes in the adjacent chapter house, also known as the Spanish Chapel. Here, in 1366-68, Andrea Bonaiuti executed painted what is rightly considered one of the most important fresco cycles in Trecento Florence, remarkable both for its artistic quality and for its innovative iconographic choices. ${ }^{31}$ As is to be expected in a chapter house, one finds the Crucifixion depicted on the wall facing the entrance, with several more scenes from the Life of Christ added underneath it as well as in the vault. The remaining parts of the decoration, however, are dedicated entirely to the Dominican Order. On the entrance wall, there are episodes from the lives and martyrdoms of Dominican saints Peter Martyr and Peter of Verona, while the two side walls contain what is often referred to as the Dominican Allegories: on the one side the elaborate Triumph of St Thomas Aquinas (which has also, and perhaps more accurately, been described as the Glorification of the Wisdom of St Thomas Aquinas' Doctrines), on the other side a complex composition sometimes termed the Road to Salvation, sometimes the Path from Earthly to Heavenly Church, a road on which members of the Dominican Order are prominently depicted in the function as spiritual guides.

It is worth noting that Andrea Bonaiuti's Florentine frescoes were painted relatively shortly after Tommaso da Modena's decoration in the Dominican chapter house in Treviso, discussed earlier. When considered together, these works show a certain preoccupation of the Dominicans around that time with creating comprehensive monumental representations of their order as a whole. As, I believe, has become evident, this process involved a certain amount of experimentation and led to a range of diverse solutions from the almost genealogical yet linear arrangement in Treviso, to the combination of saints' lives and complex allegories in the Florentine chapter house, to the Dominican Tree in the adjoining cloister. In this context, there are two aspects of this development I would like to stress: First, that the image of the tree appears relatively late in the process. Apparently, to the 14th-century Dominicans it was not the most obvious choice. Second, that the Dominicans were not the only monastic order at the time creating visual self-representations like 
the ones just discussed, and they generously helped themselves from pictorial compositions devised by other, rival orders. For instance, the Triumph of St Thomas Aquinas seems to be based on similar images of the Triumph of St Augustine created in convents of the Augustinian Hermits. ${ }^{32}$ More importantly in the given context, the concept of the allegorical tree, as already mentioned, appears to have been adapted from models found in the Franciscan Order. ${ }^{33}$

It has to be emphasized once again that neither the early Franciscan Trees discussed above nor the Dominican Tree at Santa Maria Novella are genealogical trees in the strict sense of the term at all, but are derived from different types of tree diagrams. They visualize the order's founder on (or as?) the trunk of the tree, but not lying at its root. From the surviving evidence it seems that only in the 15th century, when the concept of non-genealogical "monastic trees" was already well established, did certain orders, especially the Dominicans, take the step of adopting the genealogical model of the Tree of Jesse as a means of self-representation.

This process added new layers of complexity to depictions of Dominican trees: they were now were no longer merely visualizations of one single biological metaphor ("a monastic order is like a tree"), but incorporated two sets of metaphors ("a monastic order is like a family" and "a family is like a tree"). We can get an idea of how this process might have taken place, when we look not only at the woodcut of the Dominican Tree in Turrecremata's Meditationes, but also at the text of the accompanying meditation. ${ }^{34}$ Here, we find several allegorical epithets referring to St Dominic, and one of them is patriarcha. Thus he becomes easily comparable to the figure of a Biblical progenitor like Jesse. This is followed immediately by the metaphor of Dominic as a vine planted for the salvation of mankind and bearing copious fruit. In the text, these two concepts do not appear to be directly related to one another and no direct reference is made to the pictorial composition it accompanies, nor is there an explicit mention of the Tree of Jesse. However, the use of such different allegorical concepts side by side makes it comprehensible how the generation of the Dominican Tree as a pictorial subject might have taken place. It seems debatable, however, whether the doubling of the metaphorical content described above actually strengthened the message of such imagesone could argue that, on the contrary, it actually lessened the composition's poignancy.

\footnotetext{
32 See Hansen, Bild.

33 See also Ilg, "Quasi lignum vitae", 204.

34 Turrecremata, Meditationes, 27.
} 


\section{Conclusion}

The step from non-genealogical tree diagrams to genealogical trees undertaken by the Dominicans seems only logical, especially from the retrospective point of view of our own culture, where family trees are ubiquitous. This view is, however, somewhat challenged by the fact that even in the 15th century, the Franciscans never took that step at all but rather continued to use monastic trees based on other models such as the Tree of Virtues. A representative example of this is found in a late 15th-century panel painting, now in the Musée des Beaux-Arts in Tournai. ${ }^{35}$ It replicates a composition also found in other media such as prints, where the roots of the Franciscan Tree are formed by three allegorical female personifications. They are Obedience, Poverty and Chastity, the virtues that form the core of Franciscan identity and which also correspond to the three vows undertaken by each friar upon entering the order.

So what the case of the Franciscans shows is that while adopting a genealogical model of self-conception may have been an obvious choice for late medieval monastic communities it was by no means inevitable or compelling. We therefore have to ask what led to the differing approaches employed by different monastic orders, especially Dominicans and Franciscans. ${ }^{36}$ At this point, considering the current state of research, any answer to this question can only be of a hypothetical nature, ${ }^{37}$ but it may be helpful to remember something discussed more extensively in Christina Lutter's contribution to this volume: the way(s) in which monastic groups conceived of themselves as communities were shaped not least by the rules they adhered to, and these differed significantly between Franciscans and Dominicans. The former

35 "Franziskus, eds. Stiegemann et al., 314 (cat. no. 97)" with "Meier, Franziskanischer Ordensbaum" - cf. note on p. 196.

36 While Ordensstammbäume are occasionally found in other monastic orders as well, they appear most commonly with the Dominicans and the Franciscans. See Donadieu-Rigaut, Penser en images.

37 Recently, Ulrike Ilg sought to explain the differences between Franciscan and Dominican Trees by stating, with regard to the wall painting in Santa Maria Novella: "The Dominicans of Santa Maria Novella apparently tried to outdo their Franciscan rivals by portraying Saint Dominic in a composition similar to the Tree of Jesse as the root of the tree" (Ilg, "Quasi lignum vitae", 204). This explanation, however, seems a bit too simplistic, especially since it leaves the question: if the Dominican model outrivalled the Franciscan one, why did the Franciscans not follow suit and adopt the Tree of Jesse iconography in the course of the $15^{\text {th }}$ century as well? 
followed a rule based essentially on that of St Benedict, i.e. a rule that was very much focused on obedience. In this light, it is perhaps not surprising that they resorted to the image of a tree rooted in personifications of their binding monastic vows, obedience itself being one of them. The Dominican rule, on the other hand, is adapted from that of St Augustine, and stresses concepts such as love and fraternity as the central principals of community identity. While it does not necessarily explicitly emphasize family or genealogy, this particular vision of monastic community certainly facilitates the adoption of concepts related to family ties and kinship in a way the Benedictine/Franciscan rule does not.

Admittedly, this hypothesis seems to be somewhat contradicted by the existence of Ordensstammbaum imagery based on the Tree of Jesse within the Benedictine Order itself. ${ }^{38}$ Apparently, then, following the rule of St Benedictine did not automatically stop an order from adopting genealogical ways of self-representation. On the other hand, there never appears to have been any noteworthy tradition of Benedictine tree images, and the couple of surviving examples seem to be rather isolated cases. It is questionable, therefore, how much weight should be ascribed to this particular strand of evidence. And, of course, we also need to take into account that, unlike the Benedictines, the Franciscans already had a long tradition of allegorical tree imagery at the time when other orders began to adopt the Tree of Jessemodel in the 15th century. So all in all the situation presents itself as quite complex, and a confirmation (or indeed a refutation) of the hypothesis I have just outlined definitely requires further research not only into the pictorial but also into the textual traditions within the Franciscan and Dominican Orders.

One thing that clearly seems to emerge from everything said above is that it really was the Franciscans who were the odd ones out when it came to the use of tree imagery in their visual self-representation. While they continue to stick to their very own traditions of tree metaphors, based not least on the writings of St Bonaventure, until the end of the Middle Ages, by the $15^{\text {th century all the }}$ other orders seem to have been content to appropriate the Biblical model of the Tree of Jesse. Presumably, the appeal of this Biblical model lay in the fact that it added a certain amount of prestige to Monastic Trees through its association with the genealogy of Christ, thus emphasizing a monastic order's

38 Donadieu-Rigaut, Penser en images, $245-58$. Occasionally, the model was also used by other orders such as the Cistercians and the Carthusians. See ibid., 258-59, 265-74. 
sanctity ${ }^{39}$ Moreover, by the $15^{\text {th }}$ century, the Tree of Jesse had become a popular and potent symbolic form, expressing, as Klapisch-Zuber puts it, "both the continuity of a line and the community of a lineage". ${ }^{40}$ In the case of 15th century Ordensstammbäume, the second aspect seems to have been the more important one. Rather than emphasizing a long lineage leading into the past, images such as the one in Bern create what has been described as the timeless or mythical quality of genealogy, i.e. "eine Präsenz des Anfangs in der Gegenwart, eine Gemeinschaft der ganzen Sippe [in this case of the entire order], die den toten Spitzenahn als Anwesenden unter den Lebenden vorstellt". ${ }^{4}$

The timeless quality of most Ordensstammbäume is also evident from the fact that while they imitate a genealogical model, they make little or no effort to arrange the members of a given order chronologically. In most cases, they rather employ a hierarchical model, e.g. by placing the most important saints of an order closest to its founder or by grouping high-ranking persons, such as bishops, cardinals and popes together, and awarding them a particularly prominent position within the composition. This hierarchical arrangement, however, also highlights the fact that the envisioned monastic order constitutes a community which encompasses members from a wide range of different social groups, both men and women, simple friars to high-ranking clergyman and members of the nobility (such as Margaret of Hungary, whose royal descent is made apparent by the inclusion of her coat of arms).

What Ordensstammbäume in late medieval Europe represent is therefore first and foremost the idea of a monastic order as an all-encompassing, timeless community. On the other hand, expressing the continuity of lineage-a concept central to genealogical thought-seems to be of little if any importance at all. This emphasis of present community over past lineage also marks a notable difference between European depictions of monastic genealogies and their Tibetan counterparts, which I briefly discussed at the beginning of this paper. In Tibetan monasticism, the continuous, uninterrupted tradition of learning and oral transmission from teacher to student was/is a key element; ${ }^{42}$

39 See Klapisch-Zuber, "Genesis", 122-23, who also argues that monastic orders adopted the model of the Tree of Jesse earlier than secular dynasties precisely because the orders' inherent sanctity made it easier and less blasphemous to associate themselves with the genealogy of Christ than it would have been for a secular dynasty.

40 Klapisch-Zuber, “Genesis”, 122.

41 Heck and Jahn, "Genealogie", 4.

42 Kossak, "Lineage Painting”. 
in visual representations of monastic genealogies, the depiction of an uninterrupted lineage was therefore decidedly more important than in medieval Europe, where the concept of the monastic order as a community appears to have been the crucial factor.

\section{Bibliography}

\section{Primary Sources}

Francesco Sarri OFM, I Fioretti di S. Francesco d'Assisi, da un codice della Biblioteca Reale di Torino, ed. (Florence, 1926).

Johann von Frast, Das "Stiftungen-Buch" des Cistercienser-Klosters Zwetl, ed. Fontes rerum Austriacarum-Österreichische Geschichts-Quellen. Zweite Abtheilung. Diplomata et acta, vol. 3 (Vienna, 1851).

Johannes de Turrecremata, Meditationes (Rome, 1473).

Joachim Rossl, Liber fundatorum Zwetlensis monasterii “Bärenhaut”, ed. (Graz, 1981).

\section{Secondary Sources}

Uwe Bennert, "Art et propagande politique sous Philippe IV le Bel: le cycle de la Cite", Revue de l'art 97 (1992), 46-59.

Jörg Jochen Berns, "Baumsprache und Sprachbaum. Baumikonographie als topologischer Komplex zwischen 13. und 17. Jahrhundert", in Genealogie als Denkform in Mittelalter und Früher Neuzeit, eds. Kilian Heck and Bernhard Jahn (Tübingen, 2000), 155-76.

Steffen Bogen, "Träumt Jesse? Eine ikonographische Erfindung im Kontext diagrammatischer Bildformen des 12. Jahrhunderts", in Ästhetik des Unsichtbaren: Bildtheorie und Bildgebrauch in der Vormoderne, eds. David Ganz and Thomas Lentes (Berlin, 2004), 19-239.

Lina Bolzoni, La rete delle immagini (Turin, 2002).

Angi Elsea Bourgeois, Reconstructing the lost frescoes of Santa Maria sopra Minerva in Rome from the Meditationes of Cardinal Juan de Torquemada (Lewiston, 2009).

Joanna Cannon, Religious Poverty, Visual Riches: Art in the Dominican Churches of Central Italy in the Thirteenth and Fourteenth Centuries (New Haven, London, 2013).

Luigi De Gregori, Il chiostro della Minerva e le Meditationes del cardinale Turrecremata (Rome, 1940).

Dominique Donadieu-Rigaut, "L' image d'un ordre en pleine expansion: La salle capitulaire du convent de Trévise", in Die Methodik der Bildinterpretation, ed. Andrea von Hülsen-Esch and Jean-Claude Schmitt (Göttingen, 2002), 381-413.

Dominique Donadieu-Rigaut, Penser en images les ordres religieux: XIIe-XVe siècles (Paris, 2005). 
Yvonne El Saman, "Studien zu Kapitelsaalprogrammen zwischen 1250 und 1450 in ober- und mittelitalienischen Klöstern”, (Inaugural-Dissertation, Albert-LudwigsUniversität zu Freiburg i. Br., 2000).

Esther Meier, "Franziskanischer Ordensbaum (cat. no. 97)", in Franziskus-Licht aus Assisi, Katalog zur Ausstellung im Erzbischöflichen Diözesanmuseum und im Franziskanerkloster Paderborn, eds. Christoph Stiegemann et al. (Munich, 2011), p. 314 .

Marie-Pierre Gelin, "Stirps Jesse in capite ecclesiae: Iconographic and Liturgical Readings of the Tree of Jesse in Stained-Glass Windows", in The Tree: Symbol, Allegory, and Mnemonic Device in Medieval Art and Thought, eds. Pippa Salonius and Andrea Worm (Turnhout, 2014), 13-33.

Robert Gibbs, Tomaso da Modena: Painting in Emilia and the March of Treviso 1340-80 (Cambridge, 1989).

Charlotte Gutscher-Schmid, Nelken statt Namen: Die spätmittelalterlichen Malerwerkstätten der Berner Nelkenmeister (Bern, 2007).

Dorothee Hansen, Das Bild des Ordenslehrers und die Allegorie des Wissens: Ein gemaltes Programm der Augustiner (Berlin, 1995).

Kilian Heck and Bernhard Jahn, "Genealogie in Mittelalter und Früher Neuzeit: Leistungen und Aporien einer Denkform”, in Genealogie als Denkform in Mittelalter und Früher Neuzeit, eds. Kilian Heck and Bernhard Jahn (Tübingen, 2000), 1-9.

Ingrid-Sibylle Hoffmann, Der Meister der Pollinger Tafeln: Wege der Erneuerung in der bayerischen Malerei des mittleren 15. Jahrhunderts (Weimar, 2007).

Ulrike Ilg, "Quasi lignum vitae: The Tree of Life as an Image of Mendicant Identity", in The Tree: Symbol, Allegory, and Mnemonic Device in Medieval Art and Thought, eds. Pippa Salonius and Andrea Worm (Turnhout, 2014), 187-212.

Christiane Klapisch-Zuber, "The Genesis of the Family Tree", I Tatti Studies in the Italian Renaissance 4 (1991), 105-29.

Steven Miles Kossak, "Lineage Painting and Nascent Monasticism in Medieval Tibet", Archives of Asian Art 43 (1990), 49-57.

Christina Lutter, "Locus horroris et vastae solitudinis? Zisterzienser und Zisterzienserinnen in und um Wien", Historisches Jahrbuch 132 (2012), 141-76.

Marigold Anne Norbye, "Arbor genealogiae: Manifestations of the Tree in French Royal Genealogies", in The Tree: Symbol, Allegory, and Mnemonic Device in Medieval Art and Thought, eds. Pippa Salonius and Andrea Worm (Turnhout, 2014), 69-93.

Raphaèle Preisinger, "Die Bilder des Lebens Christi im Orden des Heiligen Franziskus”, in Bild und Körper im Mittelalter, eds. Kristin Marek et al. (Munich, 2006), 315-42.

Raphaèle Preisinger, Lignum Vitae: Zum Verhältnis materieller Bilder und mentaler Bildpraxis im Mittelalter (Paderborn, 2014).

Dénes Radocsay, Wandgemälde im mittelalterlichen Ungarn (Budapest, 1977). 
Daniel Russo, "Religion civique et art monumental à Florence au XIVe siècle: La décoration peinte de la salle capitulaire à Sainte-Marie-Nouvelle", in La religion civique à l'époque médiévale et modern: Chrétienté et islam, ed. André Vauchez (Rome, 1995), 279-96.

Monika Schmelzer, Der mittelalterliche Lettner im deutschsprachigen Raum: Typologie und Funktion (Petersberg, 2004).

Alessandro Simbeni, "Il Lignum vitae sancti Francisci in due dipinti di primo Trecento a Padova e Verona", Il Santo 46 (2006), 185-213.

Jane Casey Singer, "Painting in Central Tibet, ca. 950-1400", Artibus Asiae 54 (1994), $87-136$.

Gabrielle Spiegel, "Genealogy. Form and Function in Medieval Historiography", in Gabrielle Spiegel, The Past as Text:The Theory and Practice of Medieval Historiography (Baltimore, 1997), 99-110.

Heidrun Stein-Kecks, Der Kapitelsaal in der mittelalterlichen Klosterbaukunst: Studien zu den Bildprogramen (Munich, Berlin, 2004).

Karel Stejskal, "Die Rekonstruktion des Luxemburger Stammbaums auf Karlstein", Umění N.S. 26 (1978), 535-62.

Angelus Walz OP, “Von Dominikanerstammbäumen”, Archivum Fratrum Praedicatorum 34 (1964), 231-74.

Andrea Worm, "Arbor autem humanum genus significant: Trees of Genealogy and Sacred History in the Twelfth Century", in The Tree: Symbol, Allegory, and Mnemonic Device in Medieval Art and Thought, eds. Pippa Salonius and Andrea Worm (Turnhout, 2014), 35-67. 